\title{
The influence of cultural factors on the collapse of the Greenland Norse civilization*
}

\author{
Wpływ czynników kulturowych na upadek cywilizacji grenlandzkich Wikingów
}

\author{
Ryszard F. Sadowski \\ Institute of Ecology and Bioethics, Cardinal Stefan Wyszyński University in Warsaw, Poland \\ ORCID: https://orcid.org/0000-0002-5452-2168・r.sadowski@uksw.edu.pl
}

\begin{abstract}
The understanding of the collapse of ancient civilizations is important for the understanding of very complex process happening in our civilization. The Earth is put in danger due to many reasons and some of them do not change throughout history. Because of the global range of human actions, the power reached by contemporary man is much more dangerous than it used to be centuries ago. Therefore, the understanding of the past collapses is crucial for the safety of our global village. The article shows the reasons for the collapse of the Greenland Norse civilization. It seems that the main reason was climate change but it also seems that the Greenland Norse could have survived, or at least postponed the collapse. The author indicates that cultural factors were the roots of ecological degradation and the lack of economic adaptation. The Norse knew the Inuit and their adaptive strategies but did not learn from them. It seems that the collapse of the Greenland Norse civilization was the choice of the Norse's elite. The leaders kept the society in a risky balance in order to rule over them, but finally, the fragile equilibrium was shattered and caused the collapse.
\end{abstract}

Keywords: Greenland Norse, Greenland, civilization collapse, cultural factors, environmental factors

Streszczenie: Zrozumienie upadku starożytnych cywilizacji jest ważne dla zrozumienia bardzo złożonego procesu zachodzącego w naszej cywilizacji. Ziemia jest narażona na niebezpieczeństwo z wielu powodów, a niektóre z nich nie zmieniają się na przestrzeni dziejów. Ze względu na globalny zasięg ludzkich działań i potęgę jaką dysponuje obecnie człowiek Ziemia jest dziś bardziej zagrożona niż przed wiekami. Zrozumienie przeszłości jest więc kluczowe dla bezpieczeństwa naszej globalnej wioski. W artykule przedstawiono możliwe przyczyny upadku cywilizacji grenlandzkich Wikingów. Wydaje się, że główną przyczyną upadku były zmiany klimatyczne. Wydaje się jednak także, że grenlandzcy Wikingowie mogli przetrwać, a przynajmniej opóźnić swój upadek. Autor wskazuje, że czynniki kulturowe były źródłem degradacji ekologicznej i braku adaptacji ekonomicznej. Wikingowie znali Inuitów i ich strategie adaptacyjne, ale nie wykorzystali tej wiedzy w żaden sposób. Wydaje się, że upadek cywilizacji grenlandzkich Wikingów był wyborem ich elity. Przywódcy utrzymywali bowiem społeczeństwo w ryzykownej równowadze, aby nad nim skutecznie panować, ostatecznie jednak krucha równowaga została zaburzona i przyczyniła się do upadku tej cywilizacji.

Słowa kluczowe: grenlandzcy Wikingowie, Grenlandia, upadek cywilizacji, czynniki kulturowe, czynniki środowiskowe

\section{Introduction}

The interaction between culture and nature is obvious and undeniable. Defining culture, many scholars refer to nature. Yehudi Cohen even describes culture as an extension of human physiology and

\footnotetext{
"This article was originally published in Polish as Sadowski, Ryszard. 2008. "Wpływ czynników kulturowych na upadek cywilizacji grenlandzkich Wikingów." Studia Ecologiae et Bioethicae 6: 129-152. The trans-
}

the most important tool for adapting and mastering nature (Cohen 1968). However, the definition of culture coined by Robert L. Carneiro emphasizes the fact that culture is a kind of intermediary between human and nature introduced by humans, to

lation of the article into English was financed by the Ministry of Science and Higher Education of the Republic of Poland as part of the activities promoting science - Decision No. 676/P-DUN/2019 of 2 April 2019. 
ensure their safety and survival (Carneiro 1968). It is not surprising that while analysing the collapse of the Greenland Norse civilization, the impact of its culture on the environment, which degradation became one of the main causes of its extermination, should be shown. It seems that this collapse was also influenced by the cultural choices made by Norse people, which were the direct cause of their inability to adapt to the changes taking place and resulted in the death of this civilization.

The collapses of civilizations are facts confirmed by numerous results of research. Many different theoretical concepts present different visions of what civilization is and how to understand its collapse. Joseph A. Tainter points out that today the collapse/death of a civilization is understood as a significant transformation of its characteristics or behaviours that characterize it as a cultural entity (Tainter 2004, 22-90). These characteristics should be so important that they determine the shape of what we commonly call "civilization", meaning the movements in art and architecture, literary and musical traditions and philosophical and political thought. Arnold Toynbee and Oswald Spengler, among others, are in favour of such a concept of the end of civilization. However, Pitirim Sorokin does not agree with such understanding of the concept of "death of civilization" pointing out to continuous changes taking place in every civilization, and the fact that the "death" of civilization is most frequently the beginning of another civilization created on the ruins of the previous one. The new civilization takes much of the old one and, at least to some extent, is its continuation. The moment of "death" of a given civilization is also debatable because this process is usually long-lasting (Tainter 2004, 40).

It is also problematic to define civilization itself. It is difficult to devise a clearcut criterion for distinguishing "civilised" from "uncivilised" communities. Opinions of scholars are divided in this respect. Shephard B. Clough defines civilization as "achievements in aesthetics and intellectual exploration and success in controlling the natural environment" (Clough 1951, 3). Alfred Kroeber argues that civilization should be characterized by the presence of higher values and cultural forms (Kroeber 1944, 8). Matthew Melko, in turn, describes civilization as a great and complex culture (Melko 1969, 8). Tainter's proposal to acknowledge that, despite many differences, civilization is a cultural system of a complex community seems reasonable. Whereas, the characteristics that are generally considered appropriate for civilised communities, such as rich artistic and literary traditions, are factors of social, political and economic complexity. It is this complexity that lies at the heart of civilization because developed art and literature serves social and economic purposes and social classes, which can only exist in complex communities. Therefore, civilization appears with its complexity, it exists thanks to it and disappears with it. Complexity is, therefore, according to Tainter, the basis of a civilization, which, by definition, disappears with the disappearance of complexity (Tainter 2004, 41).

This paper is based on the example of the Norse community ${ }^{1}$ which started the colonization of Greenland around 986 AD and for about five hundred years was living in this unfriendly territory. The Norse founded two colonies, known as the Eastern and Western Colony. ${ }^{2}$ The term itself is misleading because these territories were almost $500 \mathrm{~km}$ apart in the northern direction. It would be more appropriate to name them Northern and Southern Colony. The most recent studies indicate that

${ }^{1}$ The panorama of research on the Norse community is presented by Thomas McGovern with a single, comprehensive bibliography on the subject (McGovern 1990).

${ }^{2}$ The Eastern colony was larger, it was founded as the first one already at the beginning of colonization and was inhabited for the whole 500 years, probably until the beginning of the 15th century. The Western colony was much smaller and it was deserted in the second half of the 14th century. The maps of the colonies included in this study come from the article on history of Greenland (Wikipedia 2008). 
during the period of the Norse settlement in Greenland, their population was about 2,250 people. Throughout the entire period of Greenland's colonization, a total of about 25 thousand Norsemen lived there. ${ }^{3}$ They settled on 250 farms grouped in the local centre focused around 14 major churches (Diamond 2005, 235) .

${ }^{3}$ Earlier studies had much higher estimates of the Norse population. The highest numbers are given in (McGovern 1979). The author estimated the size of the Norse population at its peak at 5,000 to 6,000 and the total number of Norse living in Greenland during the whole period of five hundred years of settlement was estimated at approx. 70 thousand. Analyses carried out by Niels Lynnerup with the use of two independent demographic methods (a mathematical model and a burial study) led him to believe that the population of Greenlandic Norsemen was much smaller than McGovern reported. According to Lynnerup, the breakthrough period for their population falls in the year 1300, and its size is then at the level of approx. 2,250 people. This scholar claims that from that time the Norse population began to gradually decline and eventually disappear. Contemporary statistical data reveal that at the turn of the 20th and 21st century Greenland has a population of approx. 60 thousand people (Lynnerup 1996).

4 The distribution of Norse settlements is also discussed in (Pringle 1997, 924). It is difficult to clearly determine the number of farms. The entry in Wi-
In the case of the Norsemen, the problem of defining the collapse of civilization disappears. Their community did not undergo any less or more thorough transformation, laying the foundations for a new civilization. After 500 years of living in Greenland, the Norse became completely extinct or abandoned this inhospitable land, leaving no form of social life behind. There is no doubt about the recognition of the Norse community as a civilization. It consisted of a sufficiently large population and had a sufficiently complex social structure with the ruling elite, church and tribal structure. The Greenland Norse recognised the sovereignty of the King of Norway and relation with the Papacy, as evidenced by tithe to the Holy See and tributes to the Crusades (Diamond 2005, 242-244; McGovern 1990, 342).

kipedia under the title "History of Greenland" states that there were twice as many farms (Wikipedia 2008). The Eastern Colony supposedly consisted of approx. 500 farms, and the Western Colony of 96. The author of the Wikipedia entry also overestimated the size of the population, which according to Niels Lynnerup's research was more than twice as small. The reason for the error could be the number of farms that were mistakenly overestimated by including temporary shelters used only in summer.

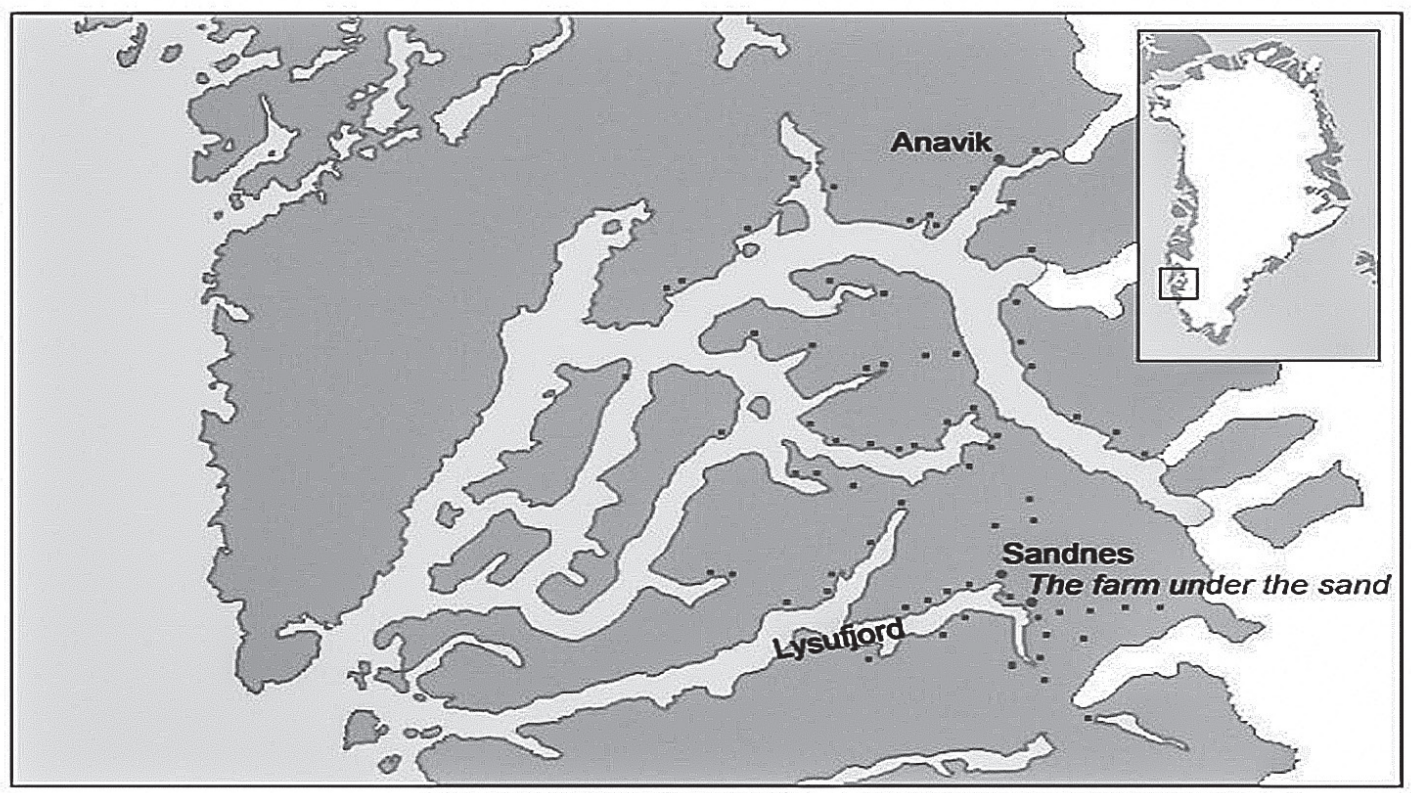

Fig. 1. Western Colony. Source (Wikipedia 2008). 


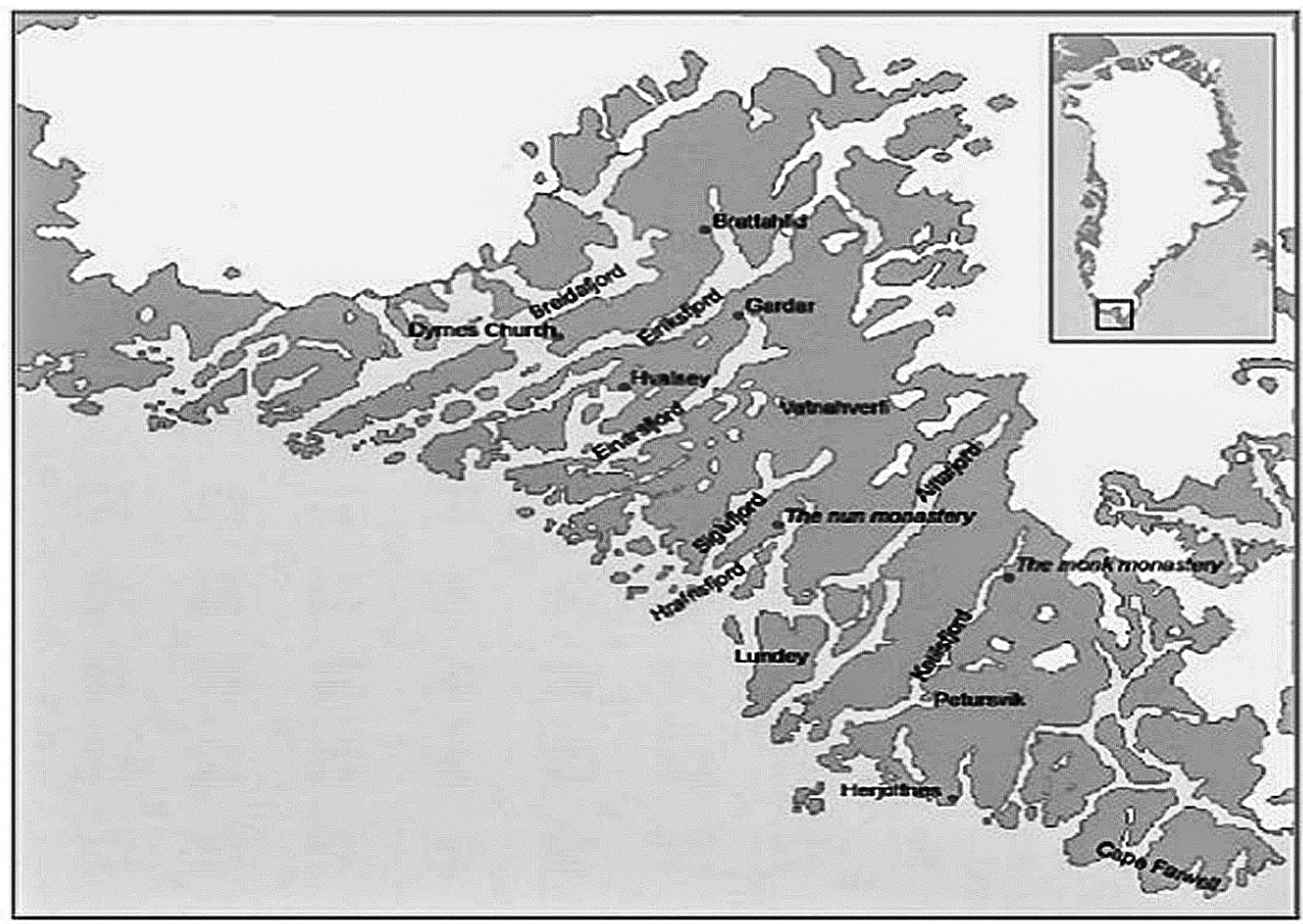

Fig. 2. Eastern Colony. Source (Wikipedia 2008).

\section{The causes of the collapse of Norse civilization in Greenland}

Analysing the collapse of individual civilizations, there are usually different causes. Joseph Tainter points to eleven most important factors that lead to collapse (Tainter 2004, 42):

1. Depletion or cessation of a vital resource or resources on which the society depends;

2. The establishment of a new resource base;

3. The occurrence of some insurmountable catastrophe;

4. Insufficient response to circumstances;

5. Other complex societies;

6. Intruders;

7. Class conflict, societal contradictions, elite mismanagement or misbehavior;

8. Social dysfunction;

9. Mystical factors;

10. Chance concatenation of events

11. Economic factors.
It seems that in the case of the Greenlandic Norsemen, the traditional division of causes, which lead to the collapse of civilization, into external ones, beyond the control of the Norse, and internal ones, which were a direct result of their decisions, can be assumed.

\section{External causes}

The external causes of the collapse of the Greenlandic Norsemen include the cooling of the climate and the distance from continental Europe. Climate change was an unforeseen disaster and, at the same time, a direct cause of what Joseph Tainter described as the "depletion of resources" necessary for a society based on a hunting and breeding economy. Moreover, the physical distance and difficult contact with the European continent made it impossible to fill these gaps.

\subsection{Climate cooling}

The progressive cooling of the climate has been a factor that has led to another factor - a significant reduction in food supplies. 
The cooling caused a shortening of the already very short vegetation period in the Norse habitats, which eventually led to the breakdown of the fragile balance they lived in for over five hundred years. The Greenlandic Norsemen were not able to secure the right amount of feed for their flocks without changing their strategy of obtaining food through the traditional form of economy based on breeding, and which could not provide food for the relatively large Norse population.

The significant difference in living conditions between the two colonies should be noted. This difference was due to their geographical location. The Western Colony $\left(64^{\circ} \mathrm{N}, 52^{\circ} \mathrm{W}\right)$ was located approx. 500 $\mathrm{km}$ north further than the Eastern Colony $\left(61^{\circ} \mathrm{N}, 46^{\circ} \mathrm{W}\right)$. The direct result of the difference in latitude was significant differences in temperature and vegetation period. In more northerly Colony temperature of above $0^{\circ} \mathrm{C}$ was maintained only for 5 months, while in the Eastern Colony (more southerly colony) this period was as much as 7 months (Diamond 2005, 215). Greenland has a colder climate than Norway or Iceland, which are heated by warm Gulf Stream. Nowadays, the climate in Greenland is similar to the one that prevailed there in the first phase of the Norse settlement. The average summer mid-day temperatures in the territories of former colonies are $5-6^{\circ} \mathrm{C}$ (Western colony) and $10^{\circ} \mathrm{C}$ (Eastern colony). The amount of annual precipitation is similar in both colonies and amounts to $600 \mathrm{~mm}$ (Diamond 2005, 214; Rutherford 1995, 324). Current studies indicate that between $800-1300$ BC climate in Greenland was relatively modest. The climatic conditions at that time were similar to those of today. At the beginning of the 14th century, the climate started to cool down rapidly, as it was the beginning of the so-called little glaciation that lasted until the early 19th century. The cooling in the 1520 s was so significant that the abundance of icebergs in the waters surrounding Greenland made sailing impossible and cut off communication between the island and mainland Europe (Diamond 2005, 219).
Contemporary studies based on the analysis of the presence of various isotopes of some elements in the ice allow determining climatic conditions throughout thousands of years. Whereas, based on the amount of pollen from the plants at given levels of the ice cap, it is possible to determine the length of the vegetation period and indicate which plants and in what amount managed to mature, which in turn indicates the temperature of the year. Another method of examining the state of the climate is to analyse the content of different isotopes of oxygen in the ice cap at different levels. Over the centuries, ice has been formed from water containing three different isotopes of oxygen, with an atomic mass of 16 (which is usually $99.8 \%$ of all oxygen) and 18 (approx. $0.2 \%$ ) and traces of oxygen of atomic mass 17 . There is a simple regularity in that warmer the summer of a given year, the higher was the content of oxygen with an atomic mass of 18 in snow from which the ice was formed (Diamond 2005, 217-218; Buckland et al. 1996).

Lisa Barlow from the University of Colorado determined the temperatures of individual years, from the early Middle Ages to the mid-1980s, on the basis of an analysis of the ice cap composition. Her research showed that in the 14th century, there were four major periods of unprecedented cooling, these were years: 1308-1318, 1324-1329, 1343-1362 and 1380-1384. The third and longest cooling period almost coincides with the abandonment of the Western Colony (Lynnerup 1996, 122). This date is also confirmed by the radiocarbon tests on the bones of animals killed by the last inhabitants of the colony (Pringle 1997, 925) and ice core tests conducted under the GISP2 programme ${ }^{5}$. The expedition arrived in Western Colone in approx. 1361 and did not meet any inhabitants. Based on the

${ }^{5}$ GISP2 is a program initiated at the end of 1988 by the American Office of Polar Programs. GISP2 stands for Greenland Ice Sheet Project 2. Extremely valuable discoveries were made under this program. The ice cap was drilled to the depth of $3,053.44 \mathrm{~m}$. This has opened a new era in palaeoenvironmental research in the Arctic (GISP2 2008; Buckland 1996). 
traces encountered, Ivar Bardarson, the expedition commander, was unable to assess whether the inhabitants had died of hunger or some kind of disease, or had abandoned their homes (Pringle 1997, 924).

The final moments of the Eastern Colony are similarly puzzling. Jette Arneborg, the curator of the Danish National Museum, believes that the inhabitants of this settlement did not encounter any cataclysm, but it was abandoned, as evidenced by the order left there (Pringle 1997, 925). It is difficult to determine the date of abandoning the East Colony. Niels Lynnerup states that the last written sources from this colony date back to 1408 . It is commonly assumed that the complete abandonment of Eastern Colony occurred about a hundred years later (Lynnerup 1996, 122).

When the Norsemen settled in Greenland in the 10th century, the climate in the North Atlantic region was exceptionally mild. This created sufficient conditions for the colonization of this area. It seems that the 14th-century climate cooling and an uninterrupted cycle of twenty unusually harsh winters and cool summers were the direct reasons for abandoning Western Colony (Pringle 1997, 925). The Norse settlement in Eastern Colony lasted much longer. However, the gradual cooling of the climate did not provide a chance for the survival of a community whose economy was based on agriculture and breeding.

\subsection{Distancing from the continent and lack of communication with Europe}

Another important factor that influenced the annihilation of the Greenlandic Norsemen was the distance from the continent and the rare and risky commercial contact between the Greenlandic settlements and Europe. It is difficult to identify this factor with any of the causes of the collapse of civilization mentioned by Joseph Tainter. It seems, however, that it was an important factor, although not a decisive one. The possibility of more frequent contacts would provide an opportunity to make up for the lack of resources, to exchange ideas and to open up to otherness. A trip from Norway to Greenland took more than a week and was very risky. So, usually no more than two ships were calling at Greenland every year. It happened that only one ship was calling to the Greenland shores throughout several years. The transport capacity of the ships of that time was small. With two ships per year, the cargo was on average approx. 3.5 $\mathrm{kg}$ of goods per one inhabitant of Greenland. On average, because only a few Norse have received any of imported goods, most of which were destined for luxury for the elite and the needs of the cult. Greenland, therefore, had to be self-sufficient in many respects. The most needed goods imported to Greenland were: iron (inability to produce, lack of good ore and fuel for melting), wood for building blocks and furniture, tar and grease, which were used as wood preservatives.

Climatic factors and geographical remoteness from Europe are important but are of little interest for this study. Much more crucial are causes of the collapse of the Norse settlement in Greenland, which were under their control. They provoke questions about why the Norse did not react properly to the changes taking place and allowed the fate of their civilization to end tragically.

\section{Internal causes}

The internal causes of the collapse of the Greenlandic Norse civilization include inadequate response to changing living conditions; economic factors and mystical factors. All these elements are among the causes of the collapse of civilizations mentioned by Tainter. It seems that selected causes are interdependent and there is a certain internal dynamics of their interaction. What they have in common is that these causes were conditioned by human decisions. Different strategies adopted by the Greenlandic elite may have significantly prolonged the presence of the Norse in Greenland or even ensured their survival to our times.

\subsection{Insufficient response to circumstances}

To understand the lifestyle of the Greenlandic Norsemen we will take a look at 
their annual calendar of activities. The advent of spring (late May or early June) was a crucial period for the economy of the Greenlandic settlements. It is then that migrating harp seals (Pagophilus groenlandicus) and hooded seals (Cystophora cristata) merge into pods off the coast of Greenland and together with the local harbour seal (Phoca vitulina) go out to the beaches of Greenland to breed. This was the period when it was easiest to hunt for seals gathering in large pods. The summer months (from June to August) were a period of particularly hard work, as the pigs were driven out to pasture. At that time, cattle provided an abundance of milk, which had to be processed to butter and cheese, which in turn were an important component of the diet during the winter. Some of the men at that time travelled to Labrador in order to obtain wooden building material. Other boats set off far north to hunt for bears, polar falcons and walruses. At the same time, commercial vessels (if any) from Iceland or Europe were arriving, importing goods not available in Greenland (Diamond 2005, 231).

August and September were a hectic period of haymaking and protecting the feed for the pigs before winter. At the end of August, the animals were driven back to the barns or closer to their homes. At the same time, the caribou hunting period began. The next months (from October to April) are the time of looking after animals in barns, weaving and repairing clothes and house renovations, as well as the processing of walrus tusks hunted in summer. The cold winter was also a time of fervent prayer so that the food and fodder gathered and the accumulated reserves of fuel would not run out before the end of the harsh winter. It seems that none of the settlements was self-sufficient. Mutual trade was necessary. While the southernmost settlements teem in better pastures, the northern settlements had more abundant hunting grounds. So the Norse exchanged their resources, thus filling in the local gaps. This is evidenced by excavations revealing numerous seal bones on farms situated far from the water, and cattle bones found in settlements where breeding was impossible (Diamond 2005, 231-232).

So it is clear that the economy of the Norse was based on a combination of breeding and hunting. The economy of the Greenlandic Norsemen was much more dependent on hunting wild animals than it was in the case of the Norse living in Iceland or Norway, where much more food was obtained from breeding the flocks. There is evidence that attempts have been made to introduce breeding habits from Norway in Greenland, such as pig farming. However, the light soils of the area were especially sensitive to the devastation that these animals caused, resulting in irreversible losses in the natural environment there. So in a short time, the population of these animals was significantly reduced. Excavations have also indicated the presence of horses, which were used as draught animals. In the Greenlandic climate, cattle required much more work and care than sheep or goats. The cattle could only find the feed on their own for 3 months of the year. Sheep and goats, which were able to dig feed on their own from the frozen snow and were more resistant to weather conditions, performed much better. However, owning cows was a sign of prestige and social position, and, therefore, contrary to economic reasons, cattle breeding was forced. With climate change, the ratio of animals of different species has gradually changed in favour of goats (Diamond 2005, 222-223). ${ }^{6}$

Archaeological data indicate that the diet of the inhabitants of the very poor settlement Niaquusat marked with the W48 symbol in Western Colony consisted of seal meat $(85 \%)$, goat meat $(6 \%)$, caribou meat (5\%), sheep meat (3\%), and only $1 \%$ of beef. At the same time, in Sandnes - the

${ }^{6}$ Present-day comparative studies on cow and sheep requirements in the Eastern Colony area show that the environmental impact of one adult cow was more or less the same as ten adult sheep. It is also estimated that the ratio between the number of cows and the number of goats on the Sandnes farm (Western Colony), marked as V35, was 1 to 4.5 . The number of cows was 4 and the number of goats was 18 (McGovern et al. 1996, 116-118). 
richest farm belonging to the Western Colony, the diet of its inhabitants consisted of $32 \%$ caribou meat, $17 \%$ beef, $6 \%$ sheep meat, $6 \%$ goat meat and only 39\% seal meat. The elite of the Eastern Colony had the best dietary conditions, here the consumption of beef on the Erik the Red's farm in Brattahlid (today's Qassiarsuk) exceeded, to a large extent, the consumption of both caribou meat and sheep and even goats (Diamond 2005, 233).

Under the floor of St. Nicholas Cathedral in Gardar (today's Igalico) a skeleton of a man dressed as a bishop was found and has been meticulously examined ${ }^{7}$. As a result, it was established that the diet of this notable consisted of $75 \%$ of land-based foods (mostly beef and cheese) and only 25\% of marine foods (mostly seals). Elite members contemporary to the bishop consumed slightly less attractive food. Their diet consists of marine products in $45 \%$. The content of seafood in the food of the Norsemen depended on their social status and the location of the settlement. In the remains of the lowly people living in the Eastern Colony, traces of $78 \%$ seafood were found, and even $81 \%$ in the Western Colony (Diamond 2005, 233-234). This was caused by climatic factors. The Easter Colony farms produced three times as much animal feed as the Western Colony farms (Diamond 2005, 232). Thanks to these conditions and political and prestige considerations, there was a cowshed in Gandar which could accommodate 160 cows. Cattle were breed in quantities not compatible with the capacity of the surrounding pastures (Diamond 2005, 235).

Based on the data provided, it is clear that the economy of the Greenlandic Norsemen was ideologically controlled. The habits and likes of breeding that were brought in did not correspond to local possibilities and were contrary to the economic situation. Change of eating habits and economic strategies may have postponed the collapse of their civilization or even completely prevent it.

\footnotetext{
${ }^{7}$ Most probably these were remains of John Arnason Smyril, Bishop of Greenland between 1189 and 1209. (Diamond 2005, 234).
}

Even more mysterious is lack of fish on the tables of the Greenland Norsemen. Archaeological research carried out in various settlements confirms that the Greenlandic Norsemen almost did not eat fish at all, although they came from Norway and Iceland, where fishing was known and commonly practised. Among various animal remains found in the Greenlandic settlements less than $0.1 \%$ of all bones are fish remains. In similar Norse settlements in Iceland, Shetland and northern Norway, the percentage of is covered fish remains ranges from $50 \%$ to $95 \%$. And so, for example, during the excavations conducted by Tomas McGovern, only three fish skeletons were found among all the remains in the Vatnahverfi settlement. During the excavations conducted by Georg Nygaard for a total of 35,000 bones, only two fish remains were found. At the excavation site marked 034, where an unusually large number of fish bones were found, as many as 166 , they constituted only $0.7 \%$ of the total number of animal bones. The situation is even more strange when we take into account the constant food shortages faced by Greenlandic Norsemen and the abundance and availability of fish. Among the most common marine fish at that time were haddock (Melanogrammus aeglefinus - a large fish weighing up to $12 \mathrm{~kg}$ ) and cod. Greenland is also rich in freshwater fish, especially trout, which nowadays can be caught there with bare hands. The availability of these species during the Norse settlement period was likely similar to as today. Even if the Norsemen did not want to eat fish themselves, they could serve as dog food and thus save some seal meat for humans. However, there are no signs of such practices. Jared Diamond points out that many archaeologists involved in field research in Greenland are completely surprised that the Greenlandic Norsemen did not eat fish at all (Diamond 2005, 229). ${ }^{8}$

\footnotetext{
${ }^{8}$ The lack of fish in the diet of the Greenlandic Norsemen and the abundance of fish on the table of their cousins living outside Greenland are also confirmed by comparative studies carried out on two similar farms, as regards size and function An analysis of research carried out at a site (SVB)
} 
While Joseph Tainter lists the emergence of completely new resources among the reasons for the collapse of some civilizations, in the case of Greenland it can be assumed that the reason for their collapse was a reluctance to use easily accessible food resources. The question arises about the reasons for this reluctance. It seems that it had a cultural background and not only did it not encourage them to eat fish, but it even dissuaded them from doing so. Diamond, trying to explain such a state of affairs, puts forward a hypothesis that even though the Greenlandic Norsemen originated from a culture in which fish were an important element of food, they probably introduced a kind of nutritional taboo that prohibited eating fish. The Norse, like any community, had the taboo of not eating certain foods to emphasize their otherness from other communities - "we, noble and cleanse, do not eat those things which the members of foreign and disgusting communities enjoy". A significant part of the nutrition taboo concerns meat and fish. In the French culture, for example, frogs, snails and horses are eaten. New Guinea's people like to eat rats, spiders and beetle larvae, while Polynesians eat marine larvae. All of these foods contain many valuable nutrients. However, most representatives of Euro-Atlantic culture will not take them in their mouths. It seems that the reason why taboo is more often imposed on meat and fish than on plant foods is the fact that bacteria and parasites develop faster and easier in meat and fish, which is the cause of dangerous poisoning. Jared Diamond supposes that this was the case during Eric the Red's first years on Greenland. Probably a significant part of the then the community had to be

near the Svalbar farm on one of the islands and at a site (V51) near the Sandnes farm shows that both farms were inhabited by a similar number of people in the same period between 1000 and 1050. The remains of animals discovered at these sites confirm that Greenlandic Norsemen almost did not eat fish, however, they were passionately hunting walruses. Whereas, their cousins from a distant island ate a lot of fish and rarely participated in dangerous walrus hunting (Buckland et al. 1996, 91). poisoned with fish, which in consequence provoked aversion to eating fish and its cultural motivation and fixation. In Diamond's opinion, this was the motivation behind it: "we, Norsemen, are noble and proud people who will not be eating this type of food. We are different from these filthy Icelanders and Norwegian fish-eaters" (Dimond 2005, 230). ${ }^{9}$

\subsection{Lack of borrowing of new hunting techniques and technologies}

Another important factor in the Norse failure was their lack of adaptation to new hunting techniques. Not accepting hunting techniques and eating habits from the Inuit people was a missed opportunity for the Norse. If the Norse had established good neighbourly relations with them, at least trade, their chances of survival would increase significantly. It is not known what ultimately caused the collapse of the Norse colonies. There is also no evidence that their demise was the result of the war with the Inuits. The fact is, however, that the Inuit people have been living in the Arctic climate for much longer than the Norse and have developed many effective strategies to adapt to living in these conditions. The Inuits came to Greenland from Northern Canada. So the conditions were similar to those found in Greenland. Thus, the starting point for the Inuits and Norse was different (Diamond 2005, 255; McGhee 2008).

The Inuits used completely different hunting and travelling techniques. Even before the thousandth year AD, they have mastered the technique of hunting whales in the open sea using leather boats. They used sledges pulled by dogs and large boats for transport and travel. The Inuits used bows and arrows for hunting (Diamond 2005, 257). Thanks to whale hunting, they had an abundant source of food, which was completely inaccessible to the Norse, and thanks to this they could create larger settlements consisting of several dozen people, including 10-20 hunters and warriors. The Inuits, longer present in the Arctic climate,

\footnotetext{
9 Norsemen probably included the Inuits, with whom they had occasional contacts, to the "others".
} 
have also developed more effective strategies for building shelters. Due to a shortage of wood for fuel and building material, they developed the technique of building igloos, and they used the fat of seals and whales for lighting and heating. They also didn't need large amounts of wood for the building material, because the boats were covered with the seal skins. They used spears connected by rope with air-filled bags of leather. It was designed to slow down the escape of hit animals and protect the haul and precious blade from drowning (Diamond 2005, 258).

Thanks to these hunting techniques, the Inuit are considered to be the most sophisticated hunters in Arctic history. In addition to hunting caribou, walruses and birds (which the Norse also hunted) the Inuits also hunted (thanks to leather kayaks) seals, birds and whales, which the Norse could not do at all. The Inuits also used completely unprecedented among Norsemen technique of hunting ringed seals (Phoca hispida), which were present in Greenland waters in great number. The habits of these seals made them very difficult prey for hunters. Ringed seals, during the winter period, melted the ice channels leading to the surface with the warmth of their bodies, which they used afterwards to take in air. For safety reasons, each seal had several of these breathing holes. This posed a considerable challenge to the hunter, who waited patiently, in the darkness of the Arctic winter, for the seal to swim into the hole to inflict a fatal blow on it. This required a great deal of patience and resistance to cold from the hunter, because he had to maintain almost perfect silence and stillness. The Norse have never borrowed this technique, and they did not have the iron to make the right spears (Diamond 2005, 260).

Although Norsemen and the Inuits have been in the same areas for several centuries, there are only 3 small mentions of contacts with the Inuits in the Norse chronicles. These mentions refer to incidental contacts between the two parties. Their authors indicate that these contacts were of a hostile and turbulent nature and, depending on the circumstances, ended in the death of one or the other. This fits the image we know from other stories about temper and impulsiveness of the Norse. These testimonies explain why they have not been able to establish neighbourly relations with the Inuits over the centuries and borrow hunting techniques and methods of adaptation to the Arctic environment (Diamond 2005, 261-262; Buckland et al. 1996, 94).

The only sure evidence of the Inuit's direct contact with the Norse is provided by the Inuit sculptures depicting human figures dressed in characteristic Norse costumes. ${ }^{10}$ Most likely it was the Inuits who borrowed some technologies from the Norse that they did not know before. This especially involves the shape they gave to their knives (they could copy it from the Norse without their help). The Inuits also learned how to produce barrels made of wooden caps and screwed arrowheads. That suggests that they must have seen them manufacturing these items. By contrast, with the Norse, there are almost no objects that might have belonged to the Inuit. ${ }^{11}$

At the archaeological sites exploring Norse settlements, not even the slightest traces of spears, spear throwers or leather Inuit boats were found. This indicates that most likely there was no trade between these peoples. There are also no anthropological or genetic traces of mixed marriages (Diamond 2005, 263).

\subsection{Economic factors}

The Norse clearly identified themselves with European culture and their contacts with the continent were extremely important to them, both in terms of the culture

10 The original wooden sculpture found in the 13th century Inuit dwelling on Baffin Island is in the National Museums of Canada. The second important artefact proving that the Inuits somehow obtained objects from the Norse is a piece of bronze scale used by the Norse. This fragment, which was found in the Inuit settlement on the west coast of Ellesmere Island, is also in the collection of the $\mathrm{Na}$ tional Museums of Canada (McGhee 2008).

${ }^{11}$ During all the excavations carried out so far in the Norse habitats, only 5 items that could belong to the Inuits were found (Diamond 2005, 262-263). 
and economy. Trade with Europe required the Norse to present an attractive offer in the form of rare or completely inaccessible for the inhabitants of continental Europe goods. They were used as a payment for the goods transported to Greenland and at the same time, they encouraged the captains of the ships to make risky trips to Greenlandic ports. Such goods included polar animals and woollen clothing produced by the Norse. Although the Western Colony was much smaller ${ }^{12}$ and had worse breeding conditions, it was of great importance for their economy due to much easier access to the northern hunting grounds. These grounds were rich in animals whose skins and trophies could be traded with ships arriving in Greenland (Diamond 2005, 232).

In the middle of the 13th century, there were times when no vessels entered Greenland for many years in a row. In 1257, Haakon Haakonsson, king of Norway sent three commissioners to confirm his authority over Greenland. It seems that it was not until 1261 that the king's rights were recognized by the Norse in exchange for the king's promise that 2 ships would arrive at the shores of Greenland annually (Diamond 2005, 243; Lynnerup 1996, 122).

Sailing from Norway to Greenland lasted a little over a week and was very dangerous due to the changeable and unfortunate weather, poorly explored waters and the presence of icebergs. For these reasons, no more than 2 ships had been arriving there per year, and sometimes it was only one ship for several years. The carrying capacity of the ships at that time was small. With two ships calling at the coast of Greenland in a year, the average annual cargo per capita was about $3 \mathrm{~kg}$. On average, because most of the Greenlandic Norsemen received very little of these products. Most of the goods from Europe were luxury items for the elite or equipment needed for worship. Greenland, therefore, had to be self-sufficient in terms of food. The most

${ }^{12}$ The size of the Western Colony is usually defined as $1 / 3$ of the Eastern Colony. It was probably formed by 25 farms scattered over a fairly large area, 3-5 km apart (McGovern et al. 1996, 115). necessary things they were not able to get on their island were: iron (lack of good ore and melting fuel), wood for building blocks and furniture, and tar and grease as a preservative for wood. Many of these products were imported in very small quantities due to limited financial possibilities and large expenditure on goods exclusive to the elite. ${ }^{13}$

In exchange for the products they bought, the Norsemen provided their $\mathrm{Eu}$ ropean contractors with goat, cow and seal skins and woollen clothes that were waterproof, and also highly valued polar animals in Europe. ${ }^{14}$ The Norsemen had to travel hundreds of miles north of West Colony for hunting in order to get the products for exchange. They used six-person open rowboats with sail, which could sail about 20 miles a day and were able to take on board up to 1.5 tons of cargo. So the hunters sailed out in June at the peak of the seal fishery and it took them about 2 weeks to arrive from West Colony or 4 weeks from East Colony. They did not return to their settlements until the end of August. In these boats, they were unable to bring meat from hunted animals, but only trophies for sale and possibly live polar bear cubs or falcons (Diamond 2005, 240-241).

To learn about the economy of the Norsemen, Tomas McGovern spent almost 20 years on field research analysing bones of animals found in the Normandy

${ }^{13}$ Examples include church bells, stained glass windows, bronze candlesticks, mass wine, linen, silk, silver, church robes and jewellery. Luxury items found on Greenland include: tinware, ceramics, glass beads and buttons and small quantities of luxury food: honey and salt.

${ }^{14}$ The most frequently exported products were: walrus tusks and skin (especially valued for their strength for ship's rope production), live polar bears and their skins, which were a sign of power and a symbol of high social status in Europe. The living polar falcons (the largest species of falcons) were also of great value. The walrus tusks replaced ivory in $\mathrm{Eu}-$ rope, as after the Muslims took control of the Mediterranean Sea, they blocked trade with India and Africa. The value of falcons is evidenced by the fact that the son of the Duke of Burgundy was bought out of captivity in 1396 for 12 of these birds. 
settlements spread over Greenland. Based on these studies he determined the size and species of animals bred and even the Norsemen's eating habits. The vast material collected during this period was compared with historical sagas about the life of these people. He confirmed earlier assumptions about hunting expeditions to the north to get walrus tusks and skins for trade with merchants (McGovern 1990, 342). He also confirmed the fact that the Norsemen were engaged in sheep, goat and cattle breeding and hunting for caribou and seals. Long-term research has led McGovern to believe that the inhabitants of both colonies hardly consumed any fish at all. This is also confirmed by studies of Bukland, who characterizes the culture of these people as follows: "So it was a non-Marine culture on the seashore" (Pringle 1997, 924).

Hunting entailed a great deal of risk, as there were often death incidents of individual hunters or entire groups of hunters. A significant issue was that the most agile men left the settlements at the time when the farms had the most work. Often, the summer work on the farm was decisive for the survival of the settlement during the winter. Moreover, the animals and their trophies were invested with great effort in items that in no way contributed to improving the quality of life of average inhabitants. They also did not prevent the coming doom.

So the Norsemen did not have the means to buy metal tools that would make haymaking and hunting easier and more efficient. Instead of metal tools, they would have to use tools made of bone and stone. Working with them required more effort and, above all, time, which was most lacking during the short summer period (Diamond 2005, 252).

The changes associated with the cooling of the climate have also been overlapping with the unreasonable economy. After arriving in Greenland, Norsemen burned out the forests for pastures, which in turn caused the erosion of the soil by strong winds present in the local climate. They also exploited the peat resources for fuel.
Pigs bred in the first phase of the settlement also had a significant impact on soil erosion (Diamond 2005, 252; McGovern et al. 1996, 120-121). ${ }^{15}$ The expenses related to the maintenance of temples and church hierarchy were an important factor influencing the economy of the Greenlandic Norsemen. A strong sense of identification with Christianity and European culture explains some of their behaviours and decisions. Today, we can say that these behaviours were the wrong reaction to the problems that occurred (maladaptive) and ultimately ended their lives.

Greenland has accepted Christianity around $1000 \mathrm{BC}$ - more or less at the same time as Norway and Iceland and other Norsemen colonies in the Atlantic region. For over 100 years, the Greenlandic churches were relatively small and they used peat and stone to build them. They were usually built in large farms. Around 1118, Einar Sokkason was sent by the Norsemen to Norway to convince the king to assign a bishop for Greenland. The mission was successful and the first bishop residing in Greenland was Arnald; there were 9 other bishops after him. Without exception, they were all born in Europe and received their education there. So it is no wonder that they looked at European customs as a model of their behaviour and preferred them over local customs. For example, they preferred beef over seal meat and encouraged hunting expeditions to the north to obtain the resources needed for trade. It was the only way for them to obtain the goods necessary for worship: mass wine, liturgical vestments, books and other ecclesiastical equipment and even stained glass windows and church bells (Diamond 2005, 243).

Bishop Arnald was sent to Greenland by Siegfried Jorsalfar, king of Norway, in 1124. For a long time, however, he re-

\footnotetext{
${ }^{15}$ Other views on soil erosion and its causes are presented in G. K. Rutherford. On the basis of the chemical and mineralogical research carried out, he argues that there is no reason to believe that the Norsemen have sterilised the soils, which were unable to yield at the current level (Rutherford 1995, 327).
} 
fused to succeed to the see, arguing that the Norsemen are quarrelsome and impulsive. He finally agreed to accept the dignity of the Bishop of Greenland provided he is granted a security guarantee confirmed by an oath taken by Einar Sokkason, son of one of the Greenlandic rulers. Einar pledged to defend the integrity of the bishop and church property. Despite the numerous dangers of his diocese, Bishop Arnald died a natural death. He managed to survive only through political efficiency and cleverness, as evidenced by the Saga of Einar Sokkason (Diamond 2005, 236-237).

With the arrival of the first bishop in Greenland, the Norsemen started to build churches. With small interruptions, construction work lasted practically until 1300. A cathedral, 13 large churches and even a monastery were built at that time. Most of the churches were built on a stone substructure, while the walls were constructed of peat. Only the Hvalsey church and three other Greenlandic temples were built entirely of stone. These churches were disproportionate to the needs of the communities that built and maintained them. For example, St. Nicholas' Cathedral in Gardar was $32 \mathrm{~m}$ long and $16 \mathrm{~m}$ wide and it was as big as the cathedrals in Iceland, where the population of believers was ten times bigger. Gardarian cathedral was built of stone blocks weighing up to 3 tons, which had to be transported from the areas a few kilometres away. A rock block, weighing around 10 tones, was placed in front of the Bishop's house and a bell tower with a height exceeding $24 \mathrm{~m}$ was built as well as a ceremonial hall with an area of $130 \mathrm{~m}^{2}$ (the largest room in Greenland at the time). Two cathedral cowsheds were almost the same size (one of them was over $63 \mathrm{~m}$ long) (Diamond 2005, 244; McGovern 1990,342$).{ }^{16}$

${ }^{16}$ F. Fernandez-Armesto reports that at the peak of its development, there were 17 monasteries and stone churches with bronze bells in the town of Brattahild itself. This information seems a bit exaggerated if one takes into account the latest research showing that the maximum population of Norsemen inhabiting the whole Greenland barely exceeded 2000 people. Although Brattahild was a settlement founded by Erik
The construction of churches and cathedral used a great deal of precious wood and a lot of priceless time needed for the construction itself and for the hunting to obtain funds for the purchase of materials and equipment for these monumental buildings. Besides, the expenditure related to the purchase of bells, wine and other objects of worship consumed all available resources which could be used to purchase much-needed tools to develop new agricultural and hunting techniques. The Norsemen, as declared Christians, like all other believers, paid tithe and tax on the Crusades to the Holy See. ${ }^{17}$

\subsection{Mystical factors}

Among the causes of the collapse of civilization, Joseph Tainter lists mystical factors. Many scholars believe that the reason for the decline of the Norsemen civilization was the attachment to Christianity. It seems, however, that this approach is too simplistic. Christianity itself is rather a criterion, which the Greenlandic Norsemen adopted to distinguish themselves from the surrounding foreign communities. It was not religious fundamentalism that caused the over-investment in the religious sphere, but rather cultural Eurocentrism, with which the Norsemen equated Christianity. A closer analysis of their decisions rather indicates that the religion was an expression of their Europeanness, to which they were very attached and for which they were ready to pay a very high price.

Jared Diamond, characterizing the Norsemen mentality, indicates that they created communities of communitarian, hierarchical, conservative, violent and Eurocentric nature. All these features are present in the Norsemen settled in Iceland, Shetland and the Faroe Islands. However, in the case of the Greenlandic Norsemen, these features are in an extreme form (Diamond 2005, 235).

the Red and belonged to the richest people in Eastern Colony, it was Gardar that was the seat of the bishop (Fernandez-Armesto 2008, 50-52).

17 Tributes for the period 1274-1280 for the Crusade cost them $667 \mathrm{~kg}$ of walrus tusks (from 191 animals) (Diamond 2005, 244). 
Their violence and conservatism had a huge impact on the quality of relations with neighbouring peoples (Diamond $2005,265)$. Violence was also a cause of failure of settlement in America. The conflict with the Native Americans, which started very quickly, became a direct cause for the Norsemen to leave the first American settlements. The relationships with the Inuit people were similar. Aggression and violence of the Norsemen did not allow for the establishment of friendly or at least neutral contacts, the lack of which proved to be crucial for their survival.

It can be assumed that in addition to ideological (Eurocentric) reasons for hostile relations with the Inuit people, there were also practical considerations, because of which there were no mixed marriages which would allow easy and effective cultural borrowing. A Norseman couldn't marry an Inuit because she couldn't weave, milk and work with the cows and prepare the cheese for winter. Even if a Norse hunter would have befriended an Inuit hunter, he was still unable to borrow a leather boat from him and hunt for seals, because the boats were made to size and only their owners could use them (Diamond 2005, 264).

Everything seems to indicate that the cultural flow between the Norsemen and the Inuit was only in one direction. The Inuits borrowed some techniques from Norsemen, but not the other way around. Archaeological research confirms that there were no systematic contacts between these peoples. McGovern emphasises in this respect the importance of religious reasons, which, in his opinion, caused such a hostile attitude of Christian Norsemen towards pagan-Inuit people. However, such an approach seems an oversimplification, similar to the fact that religion was the main reason for the war in the Balkans in the late 20th century. Holding onto $\mathrm{Eu}$ ropean culture and rejecting contact with the closest neighbours cost the Norsemen the price of biological survival. They preferred to eat their last cows and even hunting dogs and starve to death, while the Inuits hunted for the abundant seals around them. However, the Norsemen did not convince themselves to borrow the hunting techniques that the Inuits used (Pringle 1997, 926). It is strange because such cooperation was necessary. No single Norseman or small family group was able to survive on their own in Greenland. It is all the more strange that being doomed to cooperate within their community, they have not learned to cooperate with the neighbouring Inuits (Diamond 2005, 235).

Norse conservatism was something special. The decision to exclude fish from their menu was most likely taken at a very early stage of the colonisation of Greenland. Despite the changing climate and increasing difficulties in obtaining food. For over 450 years they haven't verified their decision and they haven't changed their mind! They also did not try to change their hunting strategies by borrowing from Inuit technology and their techniques in seal and whale hunting (Diamond 2005, 239).

It seems that the only rational reasons for such an attitude were strong Eurocentric tendencies revealed in their attachment to Christianity, which they ostentatiously demonstrated by building disproportionately large temples and allocating a significant part of their economic resources to the elements of religious worship. At the same time, the Norsemen have neglected to invest in tools and technologies that could significantly affect their quality of life.

\section{Conclusions}

To summarise the reasons for the collapse of the Greenlandic Norsemen civilization, it must be concluded that there has been an overlap of many different factors in this case. Climate change and the long distance from continental Europe are only some of them. The irrational economy causing environmental degradation also contributed significantly to the imminent disaster. However, the most probable cause of the collapse of the Greenlandic Norsemen community were cultural factors: separatism, conservatism, Eurocentrism, violence and impulsivity, which made it impossible for them to establish proper 
relations with the neighbouring people. Their cultural choices prevented them from borrowing Inuit hunting techniques and technologies that work well in subpolar climates (Pringle 1997, 925-926).

However, it would be a mistake to blame only cultural factors. It seems that an important role in the way the Greenlandic Norsemen communities functioned played internal politics and the divergence of interests of the elite and private members of their communities. Power was in the hands of secular leaders and church hierarchy. Both of these groups held most of the land, boats and controlled trade with Europe. They decided what was imported from the continent. This decision largely depended on the prestige, which these goods were supposed to bring to their owners. Utility and economy played a much smaller role in this respect.

It can be assumed that there were many alternatives to the impending catastrophe, which did not have to happen at all. It was possible to bring more iron and modern tools instead of sacred and luxurious objects for the elite. Adaptation of hunting techniques from the Inuits, the introduction of a new type of boat, less hunting expeditions to the north, and more trips for wood and iron to America. Such changes could, however, threaten the prestige of the particular interests of the ruling class. In the community at the edge of survival, it was much easier to exercise undivided power. The elites were therefore interested in bringing the community to the edge of a fragile equilibrium and keeping it that way. Borrowing the hunting techniques from the Inuits would give rise to independence even for small family groups. Such groups could completely base their existence on hunting and move from place to place depending on the season and the animals' migration. They wouldn't need the land owned by local rulers. Such social changes would marginalise the importance of elites and their power and wealth.

It seems that in the case of the Greenlandic Norsemen, there was a classic conflict of interests: short-lived interests of the elite and far-reaching interests of the whole community. Such an attitude was supported by their conservatism and their attachment to traditional ways of gaining living resources and social relations. The Norsemen came to Greenland with the baggage of cultural experiences and shared values and beliefs. They considered themselves farmers, Christians and Europeans. Their attachment to cow husbandry, the importance of hunting expeditions to the north and the construction of sanctuaries should be considered in this context, although from an economic point of view these were not profitable behaviours. The Norsemen, like other medieval European citizens, considered themselves better than pagans and non-European tribes. That explains why they didn't want to learn from the Inuit and were hostile to them (Diamond 2005, 275-276).

Looking from the perspective of modern man, we are surprised that they did not see the coming destruction. However, the Norsemen were not able to notice, gradual but systematic, changes taking place. Duration of human life and the state of knowledge about the mechanisms governing climate change and the environment did not allow them to see the imminent danger.

We do not know the exact date of death of the last Norman settlers on Greenland. The last European ship that brought them the goods, called at Greenland in 1410. When European people arrived again between 1576 and 1587, they found extinct settlements (Diamond 2005, 271). There are many hypotheses about the disappearance of the Greenlandic Norsemen. The most likely ones state that they died out. However, some believe that just as their arrival in Greenland was caused by the search for new areas to settle, the depletion of natural resources may have led them to leave their Greenlandic homes and gradually emigrate in search of more friendly European areas depopulated by epidemics. The beginnings of the outflow of young Greenlandic Norsemen could take place in the first decades of the 14th century. This emigration may have contributed to the decline of the fragile demographic 
balance. It is also possible that the at the end of East Colony, the rest of the surviving Norsemen left Greenland heading for Iceland, the Faroe Islands, Shetland or other areas leaving no trace of their decision (Lynnerup 1996, 133-134).

The analysis of the causes of the collapse of the Greenlandic Norsemen should make us more careful and cautious in observing the natural environment and trusting in politicians whose personal interests and the interests of their parties often contradict the interests of local, national or global communities. It seems that even today many members of elite deep inside believe that "the worse the better". Danger situations allow them to antagonise individual social or national groups and to achieve personal gain. Creating a sense of threat is a strong argument to convince whole societies to self-limitations at different levels.

The lesson given to us by the Norsemen should encourage us to be open to the ingenuity and inventiveness of every human culture, which may have answers to the problems we face today or will face in the future. Openness and cooperation are the most important factor guaranteeing us all a secure future. The increasingly visible phenomenon of globalisation carries many dangers, but it also guarantees the exchange of experiences of very remote communities both territorially and mentally. Globalisation is associated with the concern to preserve cultural and biological diversity. Cultural unification and impoverishment of biodiversity may deprive us of the opportunity to respond adequately to problems that will arise in the future. Globalisation processes contribute to cultural unification and narrow the spectrum of approaches to a given problem offered by different cultures. Cultural unification indirectly affects the environment by creating equal tastes and needs, which in turn forces the economy to use similar resources to deliver the expected goods and services. This contributes to depleting biodiversity and sacrificing more and more land for the cultivation of plants needed to produce fashionable and desirable goods in a given period. The price for such an attitude may be the irreversible loss of the diversity of species of flora and fauna or the destruction of the ecosystems where they live.

It seems that a greater effort should be undertaken to make the media aware of their responsibility for shaping patterns of behaviour, a reasonable level of consumption and environmentally friendly attitudes. It is difficult as the free market and the desire to make quick profits cause large companies to invest huge funds in stimulating the "appetite" for unnecessary goods. The media are not impartial in this process, as they earn a lot of money from advertising various products.

What gives us hope is the implementation of the idea of sustainable development, which approaches environmental, economic and human needs comprehensively. The European Union's legislative initiatives and the various international agreements for the environment are also encouraging optimism. But there are many disturbing signs. Hans Jonas says that as human's technical capabilities grow and the effects of his decisions go further and further, so does his responsibility (Jonas 1985). Our power over nature should make us more prudent in our decisions. Each one of them can contribute to the final boom or slump on a global scale. In the case of the modern human, the stake of these choices is much higher than in the case of the Greenlandic Norsemen. Modern human, contrary to a medieval inhabitant of Greenland, will not be able to move to other areas to continue the life of their civilization there.

\section{Bibliography}

Buckland, Paul C., Tom Amorosi, Lisa K. Barlow, Andrew J. Dugmore, Paul A. Mayewski, Thomas H. McGovern, Astrid E. J. Oglivie, Jon P. Sadler, and Peter Skidmore. 1996. "Bioarchaeological and climatological evidence for the fate of Norse farmers in medieval Greenland." Antiquity 70(276): 88-96. https:// doi.org/10.1017/S0003598X00082910.

Carneiro, Robert L. 1968. "Cultural adaptation." In International Encyclopaedia of the 
Social Sciences, vol. 3, edited by David Sills, 551-554. New York: Macmillan.

Clough, Stephen B. 1951. The Rise and Fall of Civilization. New York: McGraw-Hill.

Cohen, Yehudi A. 1968. "Culture as Adaptation." In Man in Adaptation. The Cultural Present, edited by Yehudi A. Cohen, 40-60. Chicago: Aldine Publishing Company.

Diamond, Jared. 2005. Collapse. How Societies Choose to Fail or Succeed. New York: Viking Penguin.

Fernandez-Armesto, Felipe. 2008. Cywilizacje. Kultura, ambicje $i$ przeksztatcanie natury. Warszawa: Wydawnictwo Naukowe PWN.

GISP2. 2008. "Welcome to GISP2." Accessed June 21, 2008. http://www.gisp2.sr.unh.edu.

Jonas, Hans. 1985. The Imperative of Responsibility: In Search of an Ethics for the Technological Age. Chicago: Chicago University Press.

Kroeber, Alfred L. 1944. Configurations of Culture Growth. Berkeley - Los Angeles: University of California Press.

Lynnerup, Niels. 1996. "Paleodemography of the Greenland Norse." Arctic Anthropology 33(2): 122-136.

McGhee, Robert. 2008. Inuit and Norsemen in Arctic Canada A.D. 1000 to 1400. Accessed June 21, 2008. http://www.civilization.ca/ cmc/archeo/oracles/norse/40.htm.
McGover, Thomas H. 1979. Paleoeconomy of Norse Greenland: Adaptation and Extinction in a Tightly Bounded Ecosystem. New York: Columbia University.

McGovern, Thomas H., Gerald F. Biegelow, Thomas Amorosi, and Daniel Russell. 1996. "Northern Islands, Human Error, and Environmental Degradation." In Case Studies in Human Ecology, edited by Daniel G. Bates, and Susan H. Lees, 103-152. New York-London: Plenum Press.

McGovern, Thomas. 1990. "The Archaeology of the Norse North Atlantic." Annual Review of Anthropology 19(1): 331-351.

Melko, Matthew. 1969. The Nature of Civlizations. Boston: Porter Sargent.

Pringle, Heather. 1997. "Death in Norse Greenland." Science 275(5302): 924-926.

Rutherford, George K. 1995. "Soils of Some Norse Settlements in Southwestern Greenland." Arctic 48(4): 324-328.

Tainter, Joseph A. 2004. The Collapse of Complex Societies. Cambridge: Cambridge University Press.

Wikipedia. 2008. "History of Greenland." Accessed June 21, 2008. http://en.wikipedia. org/wiki/History_of_Greenland. 